Trial design

\title{
Human Papillomavirus related issues in western Kazakhstan: protocol for a comprehensive study
}

\author{
Yerbol Z. Bekmukhambetov ${ }^{1}$, Ospan A. Mynbaev ${ }^{2,3}$, Andrea Tinelli ${ }^{2,4}$, Saule K. Balmagambetova ${ }^{1}$, \\ Arip K. Koyshybaev ${ }^{1}$, Olzhas N. Urazayev ${ }^{1}$, Elnara K. Ismagulova ${ }^{1}$, Oxana V. Zavalennaya ${ }^{1}$, Svetlana E. Koktova ${ }^{5}$, \\ Klara K. Sarkulova ${ }^{6}$, Zhanna Urazayeva ${ }^{1}$, Gulmira G. Yerimbetova ${ }^{1}$, Zhandos A. Dosakhanov ${ }^{7}$, Zhongjie Shi ${ }^{2,8}$, \\ Lin Ma ${ }^{2,9}$, Sergey V. Firichenko ${ }^{10}$, loannis P. Kosmas ${ }^{2,11}$, Kogershin A. Tauekelova ${ }^{12}$ \\ ${ }^{1}$ West Kazakhstan Marat Ospanov State Medical University, Aktobe, Kazakhstan \\ ${ }^{2}$ Moscow Institute of Physics \& Technology (State University), Dolgoprudny, Moscow Region, Russia \\ ${ }^{3}$ Russian National Research Medical University named after N.I. Pirogov, Moscow, Russia \\ ${ }^{4}$ Vito Fazzi Hospital, Lecce, Italy \\ ${ }^{5}$ Aktobe Tertiary Care Center, Aktobe, Kazakhstan \\ ${ }^{6}$ Aktobe Regional Pathomorphological Bureau, Aktobe, Kazakhstan \\ ${ }^{7}$ Mangystau Regional Oncology Center, Aktau, Kazakhstan \\ ${ }^{8}$ Children's Hospital of Michigan, Detroit, USA \\ ${ }^{9}$ Temple University, Philadelphia, USA \\ ${ }^{10}$ I.A. Yevdokimov Moscow State University of Medicine and Dentistry, Moscow, Russia \\ ${ }^{11}$ State General Hospital G. Chatzikosta, Ioannina, Greece \\ ${ }^{12}$ Uralsk State Out-Patient Clinic № 6, Uralsk, Kazakhstan
}

Received 17 May 2018, Revised 30 August 2018, Accepted 3 September 2018

(C) 2018, Bekmukhambetov Y.Z., Mynbaev O.A., Tinelli A., Balmagambetova S.K., Koyshybaev A.K., Urazayev O.N., Ismagulova E.K., Zavalennaya O.V., Koktova S.E., Sarkulova K.K., Urazayeva Z., Yerimbetova G.G., Dosakhanov Z.A., Shi Z., Ma L., Firichenko S.V., Kosmas I.P., Tauekelova K.A.

(C) 2018, Russian Open Medical Journal

Abstract: This article describes a Protocol for a study to determine a scope of Human Papillomavirus (HPV) infection and evaluate cervical cancer prevention measures in the western Kazakhstan.

Introduction - ICO (Institut Catala d'Oncologia) working group in 2015 informed that cervical cancer in Kazakhstan ranked as the 1st most frequent cancer among 15-44 aged women.

Aim - comprehensive analysis of the HPV infection across the female population to predict further trends in the cervical cancer morbidity and outline the circle of urgent preventive measures. The most important tasks are the following: to analyze a set of clinical, laboratory and socio-demographic data for identification the region-specific risk factors of the disease; to present a comparative analysis of diagnostic screening tools practiced in the region for the development corrective recommendations for existing screening strategy.

Methods - This study constitutes a mix of three different types: interview+cross-sectional study for general female population and interview+case-control study for women with the first time diagnosed cervical cancer, where women of the general sample of the same age with detected HPV infection but not affected by the disease serve as a control for those with the disease.

Anticipated Results - A high feasibility and pithiness of this study is expected. Obtaining a wide body of information relatively HPV scope and a quality of the screening process during a patient's single visit is the main strength of the research.

Conclusion - Successful implementation of challenges announced in the research can lead to changing a general vector or/and constituent parts of the existing screening program.

Keywords: Human Papillomavirus, cervical cancer, screening, cross-sectional study, western Kazakhstan.

Cite as Bekmukhambetov YZ, Mynbaev OA, Tinelli A, Balmagambetova SK, Koyshybaev AK, Urazayev ON, Ismagulova EK, Zavalennaya OV, Koktova SE, Sarkulova KK, Urazayeva Z, Yerimbetova GG, Dosakhanov ZA, Shi Z, Ma L, Firichenko SV, Kosmas IP, Tauekelova KA. Human Papillomavirus related issues in western Kazakhstan: protocol for a comprehensive study. Russian Open Medical Journal 2018; 7: e0408.

Correspondence to Saule Balmagambetova. Address: Oncology Department, West Kazakhstan Marat Ospanov State Medical University, 68, Maresyev Street, 030019, Aktobe, Kazakhstan. E-mail: sau3567@gmail.com. Phone: +77132561676. Mob.: +77055794637.

\section{Introduction}

ICO (Institut Catala d'Oncologia) working group in its annual report of 2015 informed that cervical cancer (CC) in Kazakhstan ranked the $2^{\text {nd }}$ most frequent cancer among women and the $1^{\text {st }}$ most frequent cancer between 15 and 44 years of age, with roughly calculated incidence rate 32.8 per 100,000 women standardized by age [1]. According to the IARC (International 
Agency for Research on Cancer) data as of 2012 for CC incidence by countries (data assessed Nov. 15, 2015), Kazakhstan took one of the highest places amongst at least borderline countries with 29.4 estimated age-standardized rate per 100,000, whereas corresponding index in Russia was 15.3, 13.5 in Uzbekistan and 7.5 in China respectively [2]. In the meanwhile, average incidence across less-developed countries estimated as 15.7 [3].

Despite the rapid accumulation of knowledge on the CC pathology, its total incidence and rank in causes of female mortality worldwide remains high, due to yet large number of countries not contributing enough to proper research and prevention, for example, postsoviet countries. According to metaanalysis on global availability of Human Papillomavirus (HPV) types distribution, contribution of postsoviet space is limited by $0-2$ publications annually [4]. Researchers from Russia, Rogovskaya et al., in 2013 comprehensively described current unsatisfactory status of HPV-attributable issues and related CC prevention measures accepted in aforementioned countries [5]. For example, overall HPV prevalence and types distribution still remains mostly unknown in the Republic of Kazakhstan. Studies on HPV prevalence are just begun in the country. In 2013-2014 our research group performed a pilot study in western Kazakhstan resulted in total prevalence of highly carcinogenic (HR) HPV types within $26 \%$, but the study had a lot of limitations [6].

In 2008 a system of the cervical cancer preventive measures has been established in our country, according to the State Program for the Development of Health of the Republic of Kazakhstan "Salamatty Kazakhstan". According to the Program, women to be screened are in age 30-60 years with interval every 5 years. The methods are characterized by full dominance of cytology: liquid-based cytological technology (LBC) "Cell Scan" system (manufactured by South Korea, Tech. Bio. Co) for the national program and a simple method with staining by Romanovsky-Giemsa usually used in opportunistic practices.

However, despite the presence of state-scale program, alarming growth of the $\mathrm{CC}$ incidence makes revise the existing screening design in the country.

Therefore, the present study aims to solve a wide range of issues relating to the scope of HPV infection in western Kazakhstan.

Aim of the research - comprehensive analysis of the Human Papillomavirus infection in female population in western Kazakhstan to predict further trends in the cervical cancer morbidity and determine the circle of urgent preventive measures.

Objectives of the research:

i) to determine the overall frequency of HPV detection amongst women across the region;

ii) to identify the most common HPV types with the definition of viral load in different age groups;

iii) to perform a comparative analysis of diagnostic tools for cervical cancer screening practiced in the region for development corrective recommendations for the screening strategy;

iv) to analyze a set of clinical, laboratory and sociodemographic data for identification the region-specific risk factors for cervical cancer.
Table 1. Number of urban population in each province and regional city

\begin{tabular}{|c|c|c|c|c|c|}
\hline \multirow[t]{2}{*}{ Provinces } & \multirow{2}{*}{$\begin{array}{l}\text { Capital city } \\
\text { and districts }\end{array}$} & \multicolumn{4}{|c|}{ Populations } \\
\hline & & $\begin{array}{l}\text { Density } \\
\text { per } k^{2}{ }^{2}\end{array}$ & $\begin{array}{l}\text { Total } \\
(m+w)\end{array}$ & Total (w) & $\begin{array}{c}\text { Female } \\
18-60 \\
\text { aged }\end{array}$ \\
\hline Aktobe & $\begin{array}{l}\text { Aktobe } \\
\text { province }\end{array}$ & & 834,768 & 425,436 & 270,200 \\
\hline RCC & Aktobe & 1,376 & 428,024 & 222,572 & 145,785 \\
\hline RDs of the & Alga & 5 & & & \\
\hline Aktobe & Ayteke Bi & 1 & & & \\
\hline province & Bayganin & $<1$ & & & \\
\hline & Kargaly & 3 & & & \\
\hline & Kobda & 1 & & & \\
\hline & Khromtau & 3 & & & \\
\hline & Martuk & 4 & & & \\
\hline & Mugalzhar & 2 & & & \\
\hline & Oiyl & 2 & & & \\
\hline & Shalkar & 1 & & & \\
\hline & Temir & 3 & & & \\
\hline & Yrgyz & $<1$ & & & \\
\hline Mangystau & $\begin{array}{l}\text { Mangystau } \\
\text { province }\end{array}$ & & 626,793 & 305,239 & 182,100 \\
\hline RCC & Aktau & 1321 & 184,541 & 95,961 & 59,496 \\
\hline RDs of the & Beyneu & 2 & & & \\
\hline Mangystau & Karakiya & 1 & & & \\
\hline region & Mangystau & 1 & & & \\
\hline & Munaily & 26 & & & \\
\hline & Tupkaragan & 2 & & & \\
\hline Atyrau & $\begin{array}{l}\text { Atyrau } \\
\text { province }\end{array}$ & & 594,562 & 296,030 & 176,700 \\
\hline RCC & Atyrau & 83 & 271,634 & 141,250 & 85,032 \\
\hline RDs of the & Inder & 3 & & & \\
\hline Atyrau & Isatay & 2 & & & \\
\hline & Kurmangazy & 3 & & & \\
\hline & Kyzylkoga & 1 & & & \\
\hline & Makat & 6 & & & \\
\hline & Makhambet & 3 & & & \\
\hline & Zhylyoi . .... & 3. & & & \\
\hline West & West & & 636,852 & 325,511 & 201,200 \\
\hline Kazakhstan & $\begin{array}{l}\text { Kazakhstan } \\
\text { province }\end{array}$ & & & & \\
\hline RCC & Uralsk & 405 & 278086 & 144604 & 89800 \\
\hline RDs of the & Akzhaik & 2 & & & \\
\hline West & Bokey Orda & 1 & & & \\
\hline Kazakhstan & Borili & 10 & & & \\
\hline province & Karatobe & 2 & & & \\
\hline & Kaztal & 2 & & & \\
\hline & Shyngyrlau & 2 & & & \\
\hline & Syrym & 2 & & & \\
\hline & Taskala & 2 & & & \\
\hline & Terekti & 4 & & & \\
\hline & Zelenov & 8 & & & \\
\hline & Zhanakala & 1 & & & \\
\hline & Zhanybek & 2 & & & \\
\hline Total: 4 & 4 cities, & & & & \\
\hline provinces & 35 RDs & & & & \\
\hline
\end{tabular}

Information on density and number of urban population has been extracted from the data of the National Statistics Agency "Population of the Republic of Kazakhstan by individual ethnic groups at the beginning of 2014"; http://www.stat.gov.kz.

RCC, regional capital city; RDs, regional districts; m, men; w, women. 


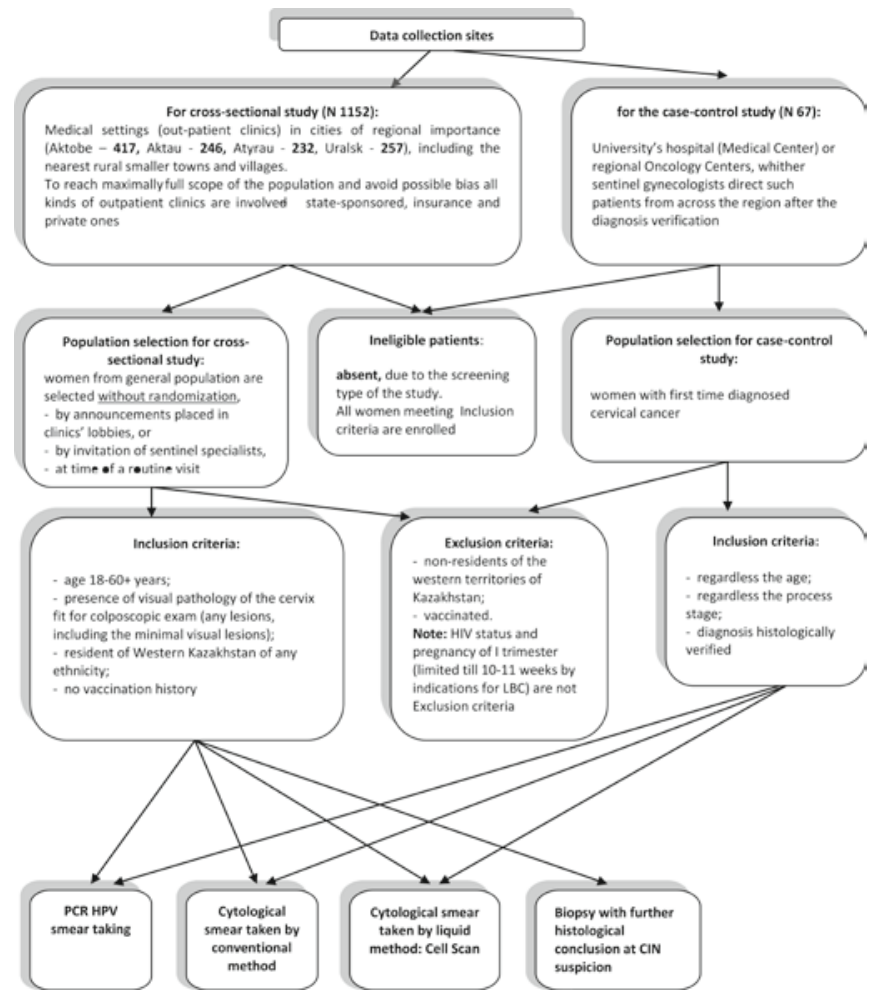

Figure 1. Flowchart of the study.

\section{Material and Methods}

\section{Study setting}

The study is registered in ISRCTN (International Standard Randomised Controlled Trial Number) registry, No. ISRCTN71514910, 02.01.2018.

The present study is held in full accordance with the Helsinki Declaration principles and the STROBE Check-list.

Research hypothesis and rationale of this study: given the high incidence of the CC (32.8 per 100,000 female population) despite the running National Cervical Cancer screening program, high prevalence of the HR-HPV along with results evidencing low efficacy of the practiced screening measures are expected. Therefore, this situation needs to be comprehensively evaluated in order to explore reasons of such a phenomenon and shortcomings of the National program.

Work is being performed by research team of the West Kazakhstan Marat Ospanov State Medical University with consultative participation of Collaborators from Italy (Salento University) and Russian Federation (Laboratory of Human Physiology, Moscow Institute of Physics and Technology (State University), indicated in Authors. All involved specialists are qualified in cervical pathology. Training for the Project staff was held by schedule in 2015. Recruitment of sentinel specialists and midwives for data collection was not implied.

HPV L1 gene sequencing is being carried out by Genetic Lab of the National Center for Biotechnology of the Committee of Science of the Republic of Kazakhstan on a basis of the Agreement of scientific cooperation (Contract № 452, 25.05.2015, Head of the Lab Zholdybayeva E.V., M.D., Ph.D.).
Study territory -4 western provinces of Kazakhstan: Aktobe, West Kazakhstan (Uralsk), Mangystau (Aktau), Atyrau.

Population density in western region -3.4 persons / sq. km.

Men / women ratio - $48 \%$ / $52 \%$.

Number of population in each province and regional city is shown in Table 1.

\section{Design and the PICOT algorithm of the combined study}

This observational study constitutes a mix of three different types: interview+cross-sectional study involving general female population and interview+case-control for women with the first time diagnosed cervical cancer, where women of the general sample of the same age with detected HPV infection but not affected by the $\mathrm{CC}$ serve as a control for those with the disease.

Survey (interview) and cross-sectional study in general sample are conducted at the same time, during a single visit. Data collection for the interview+case-control study in cancer patients is held separately, also during a single visit.

Principles of the population selection (sites, inclusion and exclusion criteria) and intervention (examination routine) are showed in Figure 1.

In determining the sample size calculation, the following points mattered:

i) according to a pilot study of the West Kazakhstan University on HPV as of 2014, N for HPV typing was 1098 , with valid statistical results on the HR-HPV prevalence as $26.04 \%$ ( $p \leq 0.043$ ) [6];

ii) from the republican statistical data as of 01.01.2014 urban female population (capitals of the provinces, suburbs and small towns, see Table 1 ) was taken across 4 provinces of western Kazakhstan (at expected HPV prevalence $\pm 25 \%$ ). In total, $N$ according to calculations in the program SAS.9.3 (two-side type I error of $p<0.05$, $\mathrm{Cl} 95 \%$ ) was 1,152, of which 417 in Aktobe, 253 in Uralsk, 237 in Atyrau and 245 in Mangystau.

When calculating sample size for the CC cases, the number of adult (18+) female population of the republic was taken and the incidence of cervical cancer in Kazakhstan (data of the Committee on Statistics of the Republic of Kazakhstan "Health of the population of the Republic of Kazakhstan and the activities of health organizations in 2014. Statistical collection of the Republic of Kazakhstan". Astana, 2015. http://www.mzsr.gov.kz) equaled $4.8 \%$. The sample size was calculated using the formula:

$$
\mathrm{N}=\frac{\mathrm{p} \times \mathrm{q} \times \mathrm{Z}_{\propto}^{2} \times \mathrm{N}}{\Delta^{2} \times \mathrm{N}+\mathrm{p} \times \mathrm{q} \times \mathrm{Z}_{\propto}^{2}}
$$

where $Z(\alpha)=1.96$ - critical values of the normal standard distribution for a given $\alpha=0.05 ; \mathrm{N}-$ number of female population of the republic $(6,700,000) ; p=0.048$ - Incidence of cervical cancer; $\mathrm{q}=1-\mathrm{p}=0.952 ; \Delta=0,05-$ sampling error. According to calculations, the sample size should be 67 people in each group ("cases" and "controls").

Examination routine consists of the following steps:

i) Acquaintance with patient and filling in the Informed Consent Form with all necessary explanations done by specialist. The form has been developed in two practiced languages, Russian and Kazakh, optional. 
ii) Interview. To reach maximally possible effectiveness of the interview all local specialists are asked to leave the room. Interview is held by the member of the research team tet-a-tet. Participants are asked to feel free - true name is not required. The text of a Questionnaire is placed below. Active assistance to patient when filling in the questionnaire is not permitted, but relevant explanations on the questionnaire issues may be done.

iii) Clinical examination. Performance of simple colposcopy; collection of polymerase chain reaction (PCR) HPV smears; collection of cytological smears by two different methods - LBC and simple cytological smear (stained by Romanovsky-Giemsa, commonly practiced in the country for opportunistic screening, especially in private clinics); performance of extended colposcopy with acetic acid and Lugole lodine; biopsy when CIN-I-II-III in general sample is supposed.

iv) Filling in blanks and forms provided by the study with further entering all information obtained into database. Guidelines for database entering is placed in the Appendix 1.

Questionnaire for the survey has been designed in semistructured, mostly closed-ended manner to provide collection of data reflecting the role of well-known risk factors in the development CC. The questionnaire also has been developed in two languages, Russian and Kazakh. Preliminary testing in focus-group has not been done. The list of questions are identical both for women from the general sample and women who were being diagnosed the disease. Content of the questionnaire is shown in Table 2.

Interpretation and grading of the answer options are also given in the Appendix 1. For validation purposes, the developed questionnaire should be analyzed for internal consistency of questions with the definition of the Cronbach's alpha, according to current requirements to such a survey [7].

\section{Comparison}

Overall, two large groups for comparison are provided by this study: HPV infected vs. not infected subjects with consequent analysis of all obtained data:

i) total HPV prevalence and distribution of leading types across the each province and each age group;

ii) data on risk factors obtained in the interview;

iii) cytological data are compared with relevant analysis of HPV findings amongst normal cytology and further towards CIN-III (Cervical Intraepithelial Neoplasia). Data on different methods (LBC "Cell Scan" vs. conventional method) are compared, involving all obtained histological conclusions which serve as an independent evaluative parameter.

For comprehensive analysis of the key risk factors, comparison by matching between the subjects from the case-control and crosssectional (general) samples is implied. Women from the crosssectional (general) sample serve as a control group for patients with diagnosed CC under the following conditions: women of the same age, infected with HPV but not affected by the cervical cancer, i.e. clinically healthy; matching in scale 1:1, i.e. 67 subjects in each group of comparison. Selection of the control group for the matching is made according the age criterion and also with the help of the random number generator, i.e. each HPV-infected, but not affected by the disease person has equal chances to get into the control group.
Table 2. Sample of the Questionnaire

\begin{tabular}{|c|c|}
\hline Issues & Answer options \\
\hline \multicolumn{2}{|l|}{ Name (first, last) (not mandatorily) } \\
\hline \multicolumn{2}{|l|}{ Date of birth } \\
\hline \multicolumn{2}{|l|}{ Address or/and contact mob. } \\
\hline \multicolumn{2}{|l|}{ Ethnicity } \\
\hline \multicolumn{2}{|l|}{ Education } \\
\hline \multirow[t]{4}{*}{ Occupation } & - Unemployed \\
\hline & - Housewife \\
\hline & - Retired \\
\hline & - Employed (occupation/profession) \\
\hline \multicolumn{2}{|l|}{ Monthly income per capita } \\
\hline \multicolumn{2}{|l|}{ Total number of pregnancies } \\
\hline \multicolumn{2}{|l|}{ Presence of close relatives with } \\
\hline \multicolumn{2}{|l|}{$\begin{array}{l}\text { cervical cancer (no matter, currently } \\
\text { or in the past) }\end{array}$} \\
\hline \multicolumn{2}{|l|}{ Age of onset of sexual activity } \\
\hline \multicolumn{2}{|l|}{$\begin{array}{l}\text { Duration of sexual life, regardless } \\
\text { duration of marriage }\end{array}$} \\
\hline \multicolumn{2}{|l|}{ Number of sexual partners during } \\
\hline \multicolumn{2}{|l|}{ lifetime, irrespective of the } \\
\hline \multicolumn{2}{|l|}{ intercourses duration } \\
\hline \multirow{2}{*}{$\begin{array}{l}\text { The use of oral contraceptives (Birth } \\
\text { control pills) }\end{array}$} & - I do not apply \\
\hline & - I use BCP \\
\hline \multicolumn{2}{|l|}{ (only for aged $<49$ ) } \\
\hline \multirow{2}{*}{$\begin{array}{l}\text { Smoking } \\
\text { (regardless lasting and number of } \\
\text { cigarettes smoked) }\end{array}$} & Yes \\
\hline & - No \\
\hline \multirow{3}{*}{$\begin{array}{l}\text { State medical institutions (PHC) } \\
\text { attendance }\end{array}$} & - Constantly \\
\hline & - Sometimes \\
\hline & $\begin{array}{l}\text { - Never, only private or insurance } \\
\text { clinics }\end{array}$ \\
\hline \multirow{3}{*}{$\begin{array}{l}\text { Participation in State Screening } \\
\text { Programs (only for aged } 30+\text { ) }\end{array}$} & - Full participation (always) \\
\hline & $\begin{array}{l}\text { - Partial participation (sometimes, } \\
\text { irregularly) }\end{array}$ \\
\hline & - Full nonparticipation \\
\hline \multirow{4}{*}{$\begin{array}{l}\text { Cervical cancer vaccination awareness } \\
\text { and perception }\end{array}$} & - I know nothing about vaccination \\
\hline & - I heard about the vaccine, but do \\
\hline & $\begin{array}{l}\text { - I would like to be vaccinated against } \\
\text { cervical cancer (I welcome) }\end{array}$ \\
\hline & $\begin{array}{l}\text { - I am strongly opposed to } \\
\text { vaccination (consider harmful) }\end{array}$ \\
\hline
\end{tabular}

* Data on income issue were taken from the site of the Committee on Statistics of the Ministry of National Economy for the IV quarter 2014 (data on living standards). The subsistence minimum which determines the poverty line amounted to KZT 18546-18774, or appr. 100-105 US\$, according to currency exchange as of November 2014; http://www.stat.gov.kz.

\section{Outcomes}

Study key endpoints:

i) Total HPV prevalence across the region and across the each province;

ii) Average viral load in HPV infected, both in general population and in the group of the CC diseased;

iii) HPV leading types in general population and in CC diseased:

iv) \% of women infected with HR-HPV types in each age categories;

v) Overall specific gravity and distribution of HPV different types in normal cytology;

vi) The most significant risk factors for the CC implementation; 
vii) Probability of the Cervical cancer (odds ratio).

Surrogate endpoints:

i) Results of comparison of two cytological methods operating in the region:

a. amount of non-informative material by each method:

b. degree of concordance with histological conclusions in each method;

c. results of receiver operating characteristics (ROC) analysis;

ii) results of Kappa statistics;

iii) Colposcopic data: correlation between HPV viral load and points of the reid colposcopic index $(\mathrm{RCl})$;

iv) Overall trend of $\mathrm{CC}$ morbidity in the region and across the each age categories;

v) Detection of various HPV gene L1 isolates circulating in the region.

\section{Time}

Data collection from each regional city is held during 3-4 trips of the research team for a period of 2 weeks. As for Aktobe, data are collected permanently.

\section{Methods and equipment for data collection \\ HPV data collection}

Smears for PCR HPV typing are taken with urogenital probe.

Qualitative and quantitative detection of HPV types is carried out with test systems "Quantum-21" (Manufacturer "DNA Technology", Russia) using thermocycler DT-prime (the same production). The company's products are certified (ISO 13485: 2012).

Thermocycler: 96-hole, 4-channel, allows to perform multiplex analysis, registered in the Republic of Kazakhstan (RK-MT-7№013267; 07.23.2014).

Test systems "HPV-21 Quantum" allow the detection of the following types: $6,11,16,18,26,31,33,35,39,44,45,51,52,53$, $56,58,59,66,68,73,82$ (total 21). Analytical sensitivity of the test-system is more than $95 \%$; data on specificity is not shown by manufacturer.

Reagent kits PROBA-NK-PLUS (the same production) are used to isolate the viral DNA, with absolute type of analysis, i.e. a certain number of viral copies in the sample is measured in genomic equivalents (GE) with a logarithmic calculation. Viral load up to $103 \mathrm{HPV}$ GE accounted for 100,000 human cells is regarded to "small", from 103 to 105 GE is regarded to "average", and GE 105 and above - to "high" respectively.

Transportation and storage of samples are carried out in accordance with the manufacturer's instructions.

\section{Cytological data collection and evaluation}

Smears by conventional method (staining by RomanovskyGiemsa) are taken with Aire spatula (ectocervix) and cytobrush (endocervix) respectively. Taking smears for LBC is performed with cytobrush, according to manufacturer instructions, as well as transportation and storage of vials. Preparations for the liquid based method are carried out on the South Korean equipment "CellScan-100" (semi-automatic) and "CellScan-200" (automatic). Preservative fluids and technology "Cell Scan» are widely used in the Republic of Kazakhstan since 2013 for the CC screening. "Cell Scan" is produced by IMSTAR technology (France) and, according to the manufacturer, tested on a representative sample of 25,000 women (the data are taken from: http://www.imstar.fr). The specificity of the test is $>85 \%$ and a sensitivity $>90 \%$. Commercial introduction and production are carried out by LTD "Tech Bio Co.", South Korea. We have found no publications on its effectiveness as well as the Russian test systems Quantum-21 in world periodicals. Interpretation and grading of smears obtained by two different methods is held according to the Terminology Bethesda System (TBS), 2001. Detailed list of all possible cytological changes for account in this study is given in the Appendix 1.

\section{Colposcopic data collection and evaluation}

Colposcopic data are collected by certified experienced members of the research team across the region. In most of medical institutions of the country South Korean video colposcopes are set. Exam is performed according to commonly accepted method. For evaluation and grading of colposcopic pictures we use classical colposcopic index by Reid [8]. Detailed list of possible colposcopic changes for account in this study is given in the Appendix 1.

Besides all aforementioned procedures HPV L1 gene sequencing is held in every case of the CC. Gene L1 is often used for sequencing in order to identify HPV types precisely and reveal their geographic path.

\section{HPV L1 sequencing method and equipment used in this research}

DNA extraction for further gene sequencing is performed using QIAamp DNA Mini Kit (Qiagen Ltd, Crawley, UK), according to manufacturer's instructions.

Amplification and sequencing of HPV L1 gene

The $\mathrm{L} 1$ gene of HPV is amplified using the consensus primers MYO9HPV 5'-CGTCCMARRGGAWACTGATC- 3 ' and MY11HPV 5' GCMCAGGGWCATAAYAATGG $-3^{\prime}$, according to commonly accepted methodics [9]. The PCR products are analyzed by $1.0 \%$ agarose gel electrophoresis and stained with ethidium bromide. Purification of PCR products from unrelated primers is carried out using an enzymatic method, Exonuclease I (Fermentas) and alkaline phosphatase (Shrimp Alkaline Phosphatase, Fermentas) as described in the manufacturer's protocol. In order to eliminate nonspecific fragments additional method of the PCR product purification by precipitation in the presence of polyethylene glycol (PEG 6000) is used. The purified DNA is used as the target for direct nucleotide sequencing using a Cycle Sequencing kit (BigDye Terminator version 3.1; Applied Biosystems, USA), followed by analysis in Genetic Analyzer 3730xl DNA Analyzer (Applied Biosystems).

Phylogenetic analyses are conducted using the MegAlign program from the LASERGENE software package (version 6.0; DNAstar, Madison, WI) and with MEGA version 5.0 software, http://www.megasoftware.net). A multiple alignment is being created through Clustal W software, and the neighbor-joining method is used for the construction of the phylogenetic tree. 
Table 3. Methods of statistical processing used in the research

\begin{tabular}{l} 
Indications for application of statistical methods \\
\hline $\begin{array}{l}\text { Analysis of internal consistency of the test (questionnaire) for the purpose of } \\
\text { validation }\end{array}$
\end{tabular}

\section{Statistical analysis}

Statistical processing of the results is held mostly on a basis of software Statistica, version 10.0 (Dell Software Inc., USA). Distribution of data is being assessed using the KolmogorovSmirnov test. In case of missing normal distribution, the median including the 25 and $75 \%$ quartiles as a measure for variability is being used in descriptive statistics. All categorical data are expressed descriptively using absolute numbers and percentages of patients, when appropriate. For all tests for group differences a two side type I error of $\mathrm{p}=0.05$ or less and confidence interval $(\mathrm{Cl})$ $95 \%$ is assumed statistically significant. All required tests and programs used in the work are presented in Table 3.

\section{Anticipated results}

Due to the comprehensive nature of the study, anticipated results involve all aspects of the HPV infection in western region of the country. Ascertainment of total HPV prevalence and leading types across the each province, being the priority in this research, is not the only task, though constitutes the main step.

Detection of leading types in women diseased with cervical cancer as well as revealing the most significant risk factors for CC development and age-specific trends of morbidity are expected to give much for future policy making with focus on implementation of compulsory vaccination program in adolescents.

Results of comparison of two cytological methods operating in the region are expected to help in elaboration more rational screening strategy focused on co-testing model (HPV+Pap). Overall, anticipated results are detailed in section Methods (Outcomes).

\section{Discussion}

In the analysis of the reasons causing CC morbidity growth, detection of the HPV prevalence is a priority. We expect obtaining data on overall prevalence of HPV types significant in terms of carcinogenicity, both from HR-HPV group (Group 1), including vaccine-targeted, and so called possibly/probably carcinogenic ones.

According to the current classification by IARC, researchers have determined 189 or even more different types of Human Papillomavirus, among them 12 are referred to the viruses of undoubtful carcinogenicity in relation to cervical cancer $(16,18$,
$31,33,35,39,45,51,52,56,58,59)$, or Group 1, whilst the role of types 68 and 73, which might be referred to the same group, still remained controversial (Group 2A) [10]. Types 66 and 82 are being considered at least potential carcinogens (Group 2B). As to the types $26,53,67,70$, also often presented in HPV assays, leading researchers as Schiffman et al., consider its role in CC development possible but relatively weak agents, albeit with the caveat that HPV's continuous evolution is the basic principle of its behaviour [11]. As an acknowledgement of the growing number of evidences of the Human Papillomavirus' constant evolution, recently Halec et al. provided molecular evidence of clear carcinogenicity for mentioned types, currently classified as probably/possibly carcinogenic [12].

At present CC research focus has moved to India, Latin America and Pacific Asia, where IARC Working Group had been performing large-scale population-based studies on screening technologies, on the basis of which 10 Key recommendations have been developed. One of them is transitioning to HPV tests as a basic screening tool [13]. HPV detection tests were also worldwide recommended by the World Health Organization not only to triage minor cytological abnormalities and follow up women after treatment of high-grade lesions, but as a primary tool [14]. In whole, currently advantage of the HPV-based CC screening is proven convincingly worldwide. There has been shown that screening with HPV testing can reduce the incidence of invasive cervical cancer by $60-70 \%$ compared to screening based on Pap tests. Thence, in recent years, the degree of evidence of this type of screening has increased to the level 1A [15]. HPV testing as the main tool is also recommended for less developed countries. A demonstration project with $\mathrm{N}=44,110$ in India showed that it was possible to implement HPV-oriented screening using the existing primary health care infrastructure [16]. As a result of this conceptual transition, in Australia since 2013 the National Cervical Screening Program's (NCSP) major changes known as "Renewal", had been started (the Program last modified 13 March 2017). Broadly, these changes involved a switch to primary testing HPV instead of former cytological domination [17, 18]. Many of countries, such as Poland, currently undertake an attempt to evaluate efficacy of their screening programs and bring them closer to the accepted standards and guidelines in advanced states [19]. As for Kazakhstan, which has previously (in 2013) adopted BD technologies and media such as SurePath, approved by FDA (US Food and Drug Administration), then crossed to "Cell Scan" 
technology, on which no Health Technology Assessment (HTA) has been published in world periodicals so far. Besides, our country has not accepted yet the WHO recommendations relating HPV primary testing.

Absence of the HPV primary testing along with growing CC morbidity convincingly demonstrates backwardness of the existing screening design in our country. Meanwhile, HPV is widely presented even in normal cytology, being early marker of potential cancer process. According to the results of well-known metaanalysis undertaken by Bernard et al., presence only type $16 \mathrm{HPV}$ in normal cytology worldwide as $16 \%$ on average and up to $50 \%$ [20]. In the aforementioned ICO group Report on Kazakhstan, paragraph on HPV presence in normal cytology still remains empty. Planned in this study detection of HPV types in normal cytology will help us to prove necessary transition to HPV-based scheme, at least in main steps similar to the Netherland', or in wider sense European screening design, most reasonable under current conditions [21].

Such supporting methods in the CC diagnostics like colposcopy are also under the constant evaluation of the researchers [22]. There is a common caveat relatively colposcopy as a diagnostic tool - along with controversial effectiveness (49-84\% on average) this method demands long apprenticeship, while VIA (Visual Innspection with Acetic acid) and VILI (Visual Inspection with Lugole lodine) methods having low cost and high PVN (negative predictive value), would be more appropriate for low-resource or remote settings, except cases of indications to biopsy [23]. For example, recent study in Morocco revealed very high acceptability of the VIA method by female population (94.5\%) [24]. Given the population density in Western Kazakhstan is very low (3.4 person per square kilometer), and for many of women living in remote villages timely colposcopic exam is often unavailable, these methods are quite worth to be considered in the context of the cervical screening effectiveness in the country. In frames of the present work we study correlations between viral load and grades of colposcopic changes in order to weigh an opportunity to implement VIA or VILI method in the most remote settings as a pilot study.

To our knowledge, state-scale vaccination of adolescents is the only effective tactics of the CC prevention. Findings of various researchers from the states accepted such an approach convincingly evidenced this as a matter of fact [25-27]. According to the aforementioned source Cancer Today [2], at present 74 countries adopted state-scale CC vaccination programs. Regrettably, successfully started in Kazakhstan in 2013 the same program had then been discontinued without relevant explanations from the Health officials, while the ICO working group informed about 6.82 million women at risk of CC in the country [1]. Evaluation of awareness and perception of vaccination in various groups of female population has never been held in the country, and we hope that such a survey should help us to outline further steps towards proper implementation of primary prevention measures in Kazakhstan.

We anticipate a high feasibility and pithiness of this study: obtaining a wide body of information relatively HPV infection and the quality of a current screening process during a patient's single visit is the main strength of the research. In fact, we perform something like a pilot Health Technology Assessment in relation the screening methods practiced in the country.

\section{Conclusion}

Primary task of the ongoing study is identifying virus types circulating in the region along with tension of viral load which eventually determine the CIN progression and deteriorate prognosis for the cervical cancer development. Evaluation of basic diagnostic tools of the cervical screening as well as key risk factors is equal by its significance and appears to be even more relevant. Successful implementation of these challenges can lead to changing a general vector or/and constituent parts of the existing screening program.

\section{Limitations}

Incomplete data of the viral types due to the test-systems partial incompatibility (Quantum-21 with 21 strains, manufactured in Russia vs. HC-II with more than 40 strains, mostly applied worldwide for HPV detection) is the key limitation of the HPV prevalence data obtained. This consideration should be taken on account when the results interpretation.

\section{Ethical approval}

All procedures performed in studies involving human participants were in accordance with the ethical standards of the institutional research committee (West Kazakhstan Marat Ospanov State Medical University) and with the 1964 Helsinki declaration and its later amendments or comparable ethical standards. The Informed Consent Form was designed according to WHO guidelines and all participants who signed the form were comprehensively informed concerning purposes of this research.

\section{Funding}

This research has been performing in frames of the scientific Project "Epidemiological analysis of Human Papillomavirus in Western Kazakhstan in relation to HPV-attributable cervical pathology - social, clinical and genetic aspects", funded by the Committee of Science of the Ministry of Education and Science of the Republic of Kazakhstan (Grant № 2230/GF4, State registration No. 0115PK01224).

\section{Conflict of interest}

All authors declare that they have no conflict of interest.

\section{References}

1. Bruni L, Barrionuevo-Rosas L, Albero G, Aldea M, Serrano B, Valencia S, et al. ICO Information Centre on HPV and cancer (HPV Information Centre). Human Papillomavirus and Related Diseases in Kazakhstan. Summary Report 23 Dec 2015. www.hpvcentre.net/statistics/reports/KAZ.pdf.

2. Ferlay J, Soerjomataram I, Ervik M, Dikshit R, Eser S, Mathers C, et al. GLOBOCAN 2012 v1.1: Cancer Incidence and Mortality Worldwide: IARC CancerBase No. 11. Lyon, France: International Agency for Research on Cancer, 2014. http://globocan.iarc.fr.

3. Bruni L, Barrionuevo-Rosas L, Albero G, Serrano B, Mena M, Gomez D, et al. ICO Information Centre on HPV and Cancer (HPV Information Centre). Human Papillomavirus and Related Diseases in the World. Summary Report 27 July 2017.

4. Wagner M, Bennetts L, Patel H, Welner Sh, de Sanjose S, Weiss TW. Global availability of data on HPV genotype-distribution in cervical, vulvar and vaginal disease and genotype-specific prevalence and incidence of HPV infection in females. Infect Agents \& Cancer 2015; 10: 13. https://dx.doi.org/10.1186/s13027-015-0008-y.

5. Rogovskaya SI, Shabalova IP, Mikheeva IV, Minkina GN, Podzolkova NM, Shipulina OY, et al. Human Papillomavirus prevalence and typedistribution, cervical cancer screening practices and current status of vaccination in Russian Federation, the Western Countries of the 
former Soviet Union, Caucasus Region and Central Asia. Vaccine 2013; 31: 7: 46-58. https://doi.org/10.1016/j.vaccine.2013.06.043.

6. Bekmukhambetov $Y Z$, Balmagambetova SK, Jarkenov TA, Nurtayeva SM, Mukashev TZ, Koyshybaev AK. Distribution of high risk human papilloma virus types in Western Kazakhstan - retrospective analysis of PCR data. Asian Pac J Cancer Prev 2016; 17(5): 2667-2672. https://www.ncbi.nlm.nih.gov/pubmed/27268648.

7. Jaglarz K, Tomaszewski KA, Kamzol W, Puskulluoglu M, Krzemieniecki $K$. Creating and field-testing the questionnaire for the assessment of knowledge about cervical cancer and its prevention among schoolgirls and female students. J Gynecol Oncol 2014; 25: 81-89. https://dx.doi.org/10.3802/jgo.2014.25.2.81.

8. Coppleson M, Pixley E, Reid B. Colposcopy; a Scientific and Practical Approach to the Cervix in Health and Disease. 3rd ed. Springfield, IL: Charles C. Thomas, 1975.

9. Qu W, Jiang G, Cruz Y, Chang CJ, Ho GY, Klein RS, Burk RD. PCR detection of human papillomavirus: comparison between MY09/MY11 and GP5+/GP6+ primer systems. J Clin Microbiol 1997; 35: 1304-1310. https://www.ncbi.nlm.nih.gov/pubmed/9163434.

10. IARC, 2012. Monographs on the evaluation of carcinogenic risks to humans, Volume $100 \mathrm{~B}$ : a review of human carcinogens: biological agents. Lyon, France: International Agency for Research on Cancer, 2012: 261-268. https://www.ncbi.nlm.nih.gov/pubmed/23189750.

11. Schiffman M, Clifford G, Buonaguro FM. Classification of weakly carcinogenic human papillomavirus types: addressing the limits of epidemiology at the borderline, Infect. Agent Cancer 2009; 4: 8. https://dx.doi.org/10.1186/1750_9378_4_8.

12. Halec G, Alemany L, Lloveras B, Schmitt M, Alejo M, Bosch FX, et al. Retrospective International Survey and HPV Time Trends Study Group. Pathogenic role of the eight probably/possibly carcinogenic HPV types 26, 53, 66, 67, 68, 70, 73 and 82 in cervical cancer. J Pathol 2014; 234: 4: 441-451. https://dx.doi.org/10.1002/path.4405.

13. ACCP: 10 Key Findings and Recommendations for Effective Cervical Cancer Screening and Treatment Programs. http://screening.iarc.fr.factsheets. php.ACCP recs 2007 factsheet final.

14. Santesso N, Mustafa RA, Schünemann HJ, Arbyn M, Blumenthal PD, Cain J, et al. World Health Organization Guidelines for treatment of cervical intraepithelial neoplasia 2-3 and screen-and-treat strategies to prevent cervical cancer. Int J Gynaecol Obstet 2016; 132(3): 252-258. https://dx.doi.org/10.1016/i.ijgo.2015.07.038.

15. Jentschke M, Hillemanns P. Systematic comparison of different metaanalyses, systematic reviews and HTA reports in Cervical Cancer screening based on cytology or HPV test. Geburtshilfe Frauenheilkd 2016; 76: 1081-1085. https://dx.doi.org/10.1055/s-0042-112457.

16. Mittal S, Mandal R, Banerjee D, Das P, Ghosh I, et al. HPV detectionbased cervical cancer screening program in low-resource setting: lessons learnt from a community-based demonstration project in India. Cancer Cases \& Control 2016; 27: 351-358. https://dx.doi.org/10.1007/s10552-015-0708-z.

17. Medical Services Advisory Committee of Australia: Australia MSAC application No1276. National Cervical Screening Program Renewal, 2013. http://www.msac.gov.au/internet/msac/publishing.nsf/Content/1276public.

18. Smith MA, Gertig M, Hall M, Simms K, Lew JB, Malloy $M$, et al. Transitioning from cytology-based screening to HPV-based screening at longer intervals: implications for resource use. BMC Health Services Research 2016; 16: 147. https://dx.doi.org/10.1186/s12913-016-1375-9.

19. Nowakowski A, Cybulski M, Sliwczynski A, Chil A, Teter Z, Seroczynski $P$, et al. The implementation of an organised cervical screening programme in Poland: an analysis of the adherence to European guidelines. BMC Cancer 2015; 15: 279. https://dx.doi.org/10.1186/s12885-015-1242-9.

20. Bernard E, Pons-Salort M, Favre M, Heard I, Delarocque-Astagneau E, Guillemot D, Thiebaut ACM. Comparing human papillomavirus prevalences in women with normal cytology or invasive cervical cancer to rank genotypes according to their oncogenic potential: a metaanalysis of observational studies. BMC Infectious Diseases 2013; 13: 373. https://dx.doi.org/10.1186/1471-2334-13-373.

21. Health Council of the Netherlands. Population screening for cervical cancer. The Hague: Health Council of the Netherlands, 2011; publication no. 2011/07E.

http://www.rivm.nl/en/Documents and publications/Common and Pres ent.

22. Bifulco G, De Rosa N. A prospective randomized study on limits of colposcopy and histology: the skill of colposcopist and colposcopyguided biopsy in diagnosis of cervical intraepithelial lesions. Infect Agents \& Cancer 2015; 10: 47. https://dx.doi.org/10.1186/s13027-0150042-9.

23. Ghosh I, Mittal S, Banerjee D, Singh P, Dasgupta S, et al. Study of accuracy of colposcopy in VIA and HPV detection-based cervical cancer screening program. Aust N Z J Obstet Gynaecol 2014; 54: 570-575. https://dx.doi.org/10.1111/ajo.12282.

24. Selmouni F, Zidouh A, Alvarez-Plaza C, El Rhazi K. Perception and satisfaction of cervical cancer screening by visual inspection with acetic acid (VIA) at Meknes-Tafilalet region, Morocco: a populationbased cross-sectional study. BMC Women's Health 2015; 15: 106. https://dx.doi.org/10.1186/s12905-015-0268-0.

25. Orlando G, Fasolo M, Mazza F, Ricci E, Esposito S. Risk of cervical HPV infection and prevalence of vaccine-type and other high risk HPV types among sexually active teens and young women (13-26 years) enrolled in the VALHIDATE study. Human Vaccines and Immunotherapeutics 2014; 10: 986-994. https://dx.doi.org/10.4161/hv.27682.

26. van Kriekinge $G$, Castellsague $X$, Cibula D, Demarteau N. Estimation of the potential overall impact of human papillomavirus vaccination on cervical cancer cases and deaths. Vaccine 2014; 32: 733-739. https://dx.doi.org/10.1016/i.vaccine.2013.11.049.

27. Osborne SL, Tabrizi SN, Brotherton JM. Assessing genital human papillomavirus genoprevalence in young Australian women following the introduction of a national vaccination program. Vaccine 2015; 33(1): 201-208. https://dx.doi.org/10.1016/j.vaccine.2014.10.045.

\section{Authors:}

Yerbol Z. Bekmukhambetov - MD, PhD, Professor, Rector of the West Kazakhstan Marat Ospanov State Medical University. https://orcid.org/0000-0002-7451-8756.

Ospan A. Mynbaev - MD, Ph.D., ScD, MSc (MedPharm), Moscow Institute of Physics \& Technology (State University), Dolgoprudny, Moscow Region, Russia; Adjunct Professor, Division of Molecular Technologies, Institute of Translational Medicine, Russian National Research Medical University named after N.I. Pirogov, Moscow, Russia. https://orcid.org/0000-00029309-1938.

Andrea Tinelli - MD, Professor, PhD, Adjunct Professor at the Laboratory of Human Physiology, Phystech BioMed School, Faculty of Biological \& Medical Physics, Moscow Institute of Physics and Technology (State University), Dolgoprudny, Moscow Region, Russia; Professor, Department of Obstetrics and Gynecology, Division of Experimental Endoscopic Surgery, Imaging, Technology and Minimally Invasive Therapy, Vito Fazzi Hospital, Lecce, Italy. https://orcid.org/0000-0001-8426-8490.

Saule K. Balmagambetova - MD, PhD, Assistant Professor, Oncology Department, West Kazakhstan Marat Ospanov State Medical University, Aktobe, Kazakhstan. https://orcid.org/0000-0003-4080-5383.

Arip K. Koyshybaev - MD, PhD, Associate Professor, Head of the Oncology Department, West Kazakhstan Marat Ospanov State Medical University, Aktobe, Kazakhstan.

Olzhas N. Urazayev - MD, PhD, Associate Professor, Oncology Department, West Kazakhstan Marat Ospanov State Medical University, Aktobe, Kazakhstan.

Elnara K. Ismagulova - MD, PhD, Professor, Head of the ENT Department, West Kazakhstan Marat Ospanov State Medical University, Aktobe, Kazakhstan. 
Oxana V. Zavalennaya - MD, Assistant Professor, Head of PCR lab at the University's Scientific Center, West Kazakhstan Marat Ospanov State Medical University, Aktobe, Kazakhstan

Svetlana E. Koktova - MD, Specialist in Colposcopy, Diagnostics Department, Aktobe Tertuary Care Center, Aktobe, Kazakhstan.

Klara K. Sarkulova - MD, Head of Cytological lab, Aktobe Regional Pathomorphological Bureau, Aktobe, Kazakhstan.

Zhanna Urazayeva - MD, the Project technician, West Kazakhstan Marat Ospanov State Medical University, Aktobe, Kazakhstan.

Gulmira G. Yerimbetova - MSc, Senior Statistician, Department of Biostatistics, West Kazakhstan Marat Ospanov State Medical University, Aktobe, Kazakhstan

Zhandos A. Dosakhanov - MD, PhD, Vice-Director of the Mangystau Regional Oncology Center, Aktau, Kazakhstan.

Zhongjie Shi - MD, PhD, Adjunct Professor, Laboratory of Human Physiology, PhysTech BioMed School, Faculty of Biological \& Medical Physics, Moscow Institute of Physics \& Technology (State University), Dolgoprudny, Moscow Region, Russia; Adjunct Professor, Department of Pediatrics, Children's Hospital of Michigan, Detroit, USA. https://orcid.org/0000-0002-1912-229X.
Lin Ma - MD, MS, Adjunct Professor, Laboratory of Human Physiology, PhysTech BioMed School, Faculty of Biological \& Medical Physics, Moscow Institute of Physics \& Technology (State University), Dolgoprudny, Moscow Region, Russia; Adjunct Professor, Department of Chemistry, Temple University, Philadelphia, USA. https://orcid.org/0000-0002-5252-6923.

Sergey V. Firichenko - MD, PhD, Associate Professor, Department of Obstetrics and Gynecology, I.A. Yevdokimov Moscow State University of Medicine and Dentistry, Moscow, Russia. https://orcid.org/0000-00018342-8317.

Ioannis P. Kosmas - MD, MSc, PhD, Adjunct Professor, Laboratory of Human Physiology, PhysTech BioMed School, Faculty of Biological \& Medical Physics, Moscow Institute of Physics \& Technology (State University), Dolgoprudny, Moscow Region, Russia; ObGyn \& Reproductive Endocrinology Specialist, Ioannina State General Hospital G. Chatzikosta, Department of Obstetrics \& Gynecology, Ioannina, Greece. https://orcid.org/0000-0002-7326-7852.

Kogershin A. Tauekelova - MD, Specialist in Colposcopy in the Uralsk State Out-Patient Clinic №6, Uralsk, Kazakhstan. 


\section{DATABASE ENTERING GUIDELINE}

Note: database is filled in Excel; information should be identical to Individual Registration Form.

Code definition:

$1 / 1 / 1$

First figure - index of researcher;

Second figure - Province's code:

1 - Aktobe; 2 - Aktau; 3 - Atyrau; 4 - Uralsk.

Third figure - index of subject.

$1 a / 1 / 1$

«a» means that the smear has been taken from a person with suspected cancer, before the histological conclusion.

VAR 1 - Age (categorical variable):

$1-18-29$

$2-30-39$

$3-40-49$

$4-50-60+$

VAR $1^{*}$ - Age in years (nominal variable):

VAR 2 - Ethnicity:

1 - Asians (Turks - Kazakhs, Bashkirs and etc)

2 - Europeans (Russians, Ukrainians, Germans and etc.)

3 - Caucasian ethnicities (mostly Azerbajanians)

VAR 3 - Education:

1 - high school

2 - professional college

3 - higher education

VAR 4 - Occupation:

1 - unemployed, housewife, retired

2 - low-skilled job (technical, stallman, seller, including small markets, etc.)

3 - medium level (an ordinary manager, seller-consultant, cashier), nurses, etc.

4 - high-skilled job - physician, teacher, lawyer, bank manager, civil official, manager, representatives of creative professions, the owners of medium-sized businesses

VAR 5 - Family monthly income:

$1-100 \$ *$ per capita (below the minimum subsistence level and poverty threshold) up to $250 \$$ per capita (relatively poor category)

$2-250$ till $500 \$$ (relatively prosperous category)

$3-\geq 500 \$-$ relatively wealthy category

*Note: Currency exchange as of November 2014.

VAR 6-Smoking:

$0-$ no

$1-$ yes (regardless lasting and number of cigarettes smoked)

VAR BCP - Oral contraceptives:

$0-$ no

$1-$ yes

VAR 7 - Duration of sexual life, regardless duration of marriage (categorical variable):

1 - from 0 up to 10 years

$2-11-20$ years

$3-\geq 20$ years

VAR 7* - Age of sexual debut (nominal variable): 
VAR $7^{* *}-$ Total duration of sexual life (nominal variable):

VAR 8 - Number of sexual partners during lifetime, irrespective of the intercourses duration (categorical variable):

$1-1$

$2-2-5$

$3-6-10+$

VAR 8* - Number of sexual partners during lifetime, irrespective of the intercourses duration (nominal variable):

VAR 9 - State medical institutions attendance:

1 - constantly

2 - sometimes

3 - never, only private or insurance clinics

VAR 10 - Participation in State Screening Programs:

1 - full participation (cervical cancer)

2 - partial participation (sometimes)

3 - complete nonparticipation

VAR 11 - CC vaccination awareness and perception:

1 - knows nothing about vaccination

2 - heard about the vaccine, but does not know how to evaluate information

3 - would like to be vaccinated against cervical cancer (welcomes)

4 - strongly opposed to vaccination (considers harmful)

VAR 12 - Hereditary factor:

0 - absence of close relatives with CC

1 - presence of close relatives with $\mathrm{CC}$

VAR 13 - total number of pregnancies (categorical variable):

$1-0$ (absence)

$2-1-2$

$3-3+$

VAR $13^{*}$ - total number of pregnancies, nominal variable, $0+$ :

VAR 14 - LBC (CellScan transportation medium and technology):

0 - B (unsatisfactory for evaluation, no material)

1 - AC (normal squamous cells)

2 - D (pathological microflora)

3-E (squamous metaplasia, reserve cells hyperplasia)

4 - F1 (ASC-US) - Atypical squamous cells of undetermined significance, cannot exclude (ASC-H)

$5-\mathrm{F} 2$ (LSIL, CIN-I)

6 - F3 (HSIL, including CIN-II, CIN-III, TIS - cancer in situ)

7 - F4 (Squamous cancer)

$8-\mathrm{G} 1$ (benign glandular cells in women over 40 years)

$9-\mathrm{G} 2$ (AGC) - Atypical glandular cells of undetermined significance, atypical glandular cells not otherwise specified (AGC-NOS)

10 - G3 Adenocarcinoma in situ

11 - G4 Adenocarcinoma

VAR 15 - Conventional cytology (Romanovsky-Giemsa):

0 - Unsatisfactory for evaluation, no material

1 - Normal squamous cells

2 - Inflammation, signs of infection

3 - Benign squamous metaplasia, reserve cells hyperplasia

4 - Squamous metaplasia with mild atypia, proliferation of the glandular epithelium with mild atypia, dyskaryosis

5 - Mild dysplasia (detection of atypical changes, CIN-I), koilocytosis

6 - Moderate or severe dysplasia (CIN-II, CIN-III or Ca in situ - TIS)

7 - Cancer (squamous)

8 - Benign proliferation of glandular cells in women over 40 years 
9 - Noticeable proliferation of atypical glandular cells, AGC-NOS

10 - Adenocarcinoma in situ

11 - Adenocarcinoma.

VAR $15^{*}-$ Histological conclusions:

1 - Normal squamous cells

2 - Inflammation, signs of infection, including chronic cervicitis

3 - Benign squamous metaplasia, reserve cells hyperplasia

4 - Squamous metaplasia with mild atypia, proliferation of the glandular epithelium with mild atypia, dyskaryosis

5 - Mild dysplasia (detection of atypical changes, CIN-I), koilocytosis

6 - Moderate or severe dysplasia (CIN-II, CIN-III or Ca in situ - TIS)

7 - Cancer (squamous)

8 - Benign proliferation of glandular cells in women over 40 years

9 - Noticeable proliferation of atypical glandular cells (AGC-NOS)

10 - Adenocarcinoma in situ

11 - Adenocarcinoma

Note: located in Database Cervical Cancer, 2 sheet.

VAR 19 - Data of colposcopic exam (categorical variable, by Coppleson-Pixley scale):

1 - usual transformation zone, weak suspicion for HPV:

Columnar ectopy, squamous metaplasia, open ducts of glands, closed ducts of glands (Nabothian cysts), typical vessels (hypervascularization permitted under normal form of vessels), borders of transformation zone are not clearly defined, absence of punctation, mosaics, leucoplakia or other atypical lesions;

$2-\mathrm{HPV}$ infection?

typical symptoms of flat genital warts, pearl acetowhite epithelium, clear boundary of lesion area, gentle mosaics and/or punctation, normal vessels;

3- Low atypical transformation zone:

relatively large affected area with clear or unclear contours, questionable vessels, presence of mild expressed foci of leukoplakia, a lot of open ducts of glands with hyperkeratosis, presence of relatively delicate mosaics and/or punctation, intensive acetic acid test, intensive Shiller (lodine) test;

4- Highly atypical transformation zone:

clear boundary of acetowhite epithelium regardless the volume of the affected area, intensive acetowhite epithelium, leukoplakia, mosaic and/or punctation are rough, there is tuberosity or ulceration, mild or severe induced bleeding of transformation zone, hypertrophic atypical vessels in the form of a corkscrew, a comma, or shapeless, in the form of logs.

VAR 19* - points of Reid Colposcopic Index from 1 up to 8, nominal variable.

Note: variable 19 is absent in Cervical cancer database.

VAR $6^{*}, 11^{*}$ till 82 - types detected:

0 - not detected

$1-<10^{3}$ copies DNA HPV (Genomic equivalents) / per $10^{5}$ cells (per sample) - of grey color

$2-10^{3}-10^{5}$ copies DNA HPV (Genomic equivalents) / per $10^{5}$ cells (per sample) - of green color

$3->10^{5}$ copies DNA HPV (Genomic equivalents) / per $10^{5}$ cells (per sample) - of red color

VAR Sum - total sum of viral load per sample (continuous variable).

VAR St - Stage of cervical cancer process by FIGO-TNM, 2009, $7^{\text {th }}$ revision (categorical variable), only for Cervical cancer database:

$1-\mathrm{TIS}$

$2-\mathrm{St}$ la

$3-\mathrm{St} \mathrm{Ib}$

$4-$ St lla

$5-\mathrm{St} I \mathrm{lb}$

6 - St IIIa

$7-$ St IIIb 